\title{
Case Report Chlamydial Pneumonitis: A Creepy Neonatal Disease
}

\author{
Kam Lun Hon ${ }^{1}$ and Alexander K. C. Leung ${ }^{2}$ \\ ${ }^{1}$ Prince of Wales Hospital, The Chinese University of Hong Kong, Shatin, Hong Kong \\ ${ }^{2}$ Alberta Children's Hospital, The University of Calgary, Calgary, AB, Canada T2N 1N4 \\ Correspondence should be addressed to Alexander K. C. Leung; aleung@ucalgary.ca
}

Received 25 December 2012; Accepted 16 January 2013

Academic Editors: D. Fischer and R. Lauterbach

Copyright (C) 2013 K. L. Hon and A. K. C. Leung. This is an open access article distributed under the Creative Commons Attribution License, which permits unrestricted use, distribution, and reproduction in any medium, provided the original work is properly cited.

\begin{abstract}
We present a case of neonatal chlamydial pneumonitis to illustrate that a high index of suspicion is necessary to make the diagnosis so that treatment can be promptly instituted. The child was afebrile and the only symptom was a cough. The respiratory equations are calculated to understand the respiratory physiology. There was no overt abnormality with ventilation, oxygenation, compliance, resistance, or ventilation-perfusion mismatch despite radiographic abnormality. The literature is searched to review if treatment with a systemic macrolide antibiotic is needed in an otherwise asymptomatic neonate with chlamydial pneumonitis.
\end{abstract}

\section{Case}

A 10-day-old full-term female presented with mild left eye discharge, which was treated with topical chlortetracycline and levofloxacin eyedrops. An eye swab yielded no bacterial pathogen and immunofluorescence test for Chlamydia trachomatis was equivocal. Ten days later, she presented with a cough for 5 days. There had been no fever and examination showed a well-appearing baby with no respiratory distress. Her respiratory rate was $40-48 / \mathrm{min}$, chest was clear, and $\mathrm{SaO}_{2}$ was $100 \%$ in room air. A chest radiograph, however, revealed interstitial pneumonitis (Figure 1). Blood culture, serial complete blood counts, and C-reactive protein levels were unremarkable. Capillary blood gas showed $\mathrm{pH} 7.30$, $\mathrm{pCO}_{2} 5.1 \mathrm{kPa}$, and $\mathrm{pO}_{2} 7.6 \mathrm{kPa}$. Shell vial culture of the eye swab subsequently yielded Chlamydia trachomatis. The child was treated with a course of antibiotics including a macrolide, and her cough resolved. Using the capillary blood gas data, assuming that $\mathrm{PaO}_{2}$ is not lower than the capillary $\mathrm{PO}_{2}$, common respiratory equations were calculated (Table 1).

\section{Discussion}

The literature was searched to address clinical questions pertinent to this case. Differential diagnoses for coughing in a neonate could include viral infections such as RSV, bacterial infection such as pertussis, gastroesophageal reflux, airway abnormalities such as tracheoesophageal fistula, and cystic fibrosis [1-3]. Isolated cough without upper respiratory tract symptoms in the family makes common respiratory viral infections unlikely. It is important to realize that not all neonates with respiratory infections present with cough, as some may become apneic instead [4]. Our case suggests that a neonate can present with cough alone without any other respiratory symptomatology. The respiratory equations confirm why her respiratory symptomatology was mild because she had relatively normal respiratory mechanics with no ARDS (acute respiratory distress syndrome), overt ventilation, oxygenation, or perfusion impairments despite abnormal chest radiography. ARDS is characterized by increased pulmonary capillary permeability and pulmonary edema that results in hypoxemia, decreased lung compliance, and bilateral diffuse alveolar infiltrates on chest radiography $[5,6] . \mathrm{PaO}_{2} / \mathrm{FiO}_{2}$ indicates that her acute respiratory symptom and diffuse radiographic patchiness did not achieve ARDS severity [5-8]. Abnormal alveolar-arterial gradient signifies a significant diffusion/shunting abnormality at the alveolar-arterial interface secondary to capillary leak and relative surfactant depletion $[7,8]$. Oxygenation index (OI, defined as mean airway pressure $\left.(\mathrm{cm}) \times \mathrm{FiO}_{2}(\%) / \mathrm{PaO}_{2}(\mathrm{mmHg})\right)$ indirectly denotes the risk and benefit ratio for management [7]. Mean airway pressure in a spontaneous breathing neonate is assumed to 
TABLE 1: Respiratory indices.

\begin{tabular}{|c|c|c|}
\hline Parameters & Data & Remarks \\
\hline Ventilation index & N/A & $\begin{array}{l}\text { Prognostic marker of lung injury } \\
\text { (http://www-users.med.cornell.edu/ spon/picu/calc/ventindx.htm) }\end{array}$ \\
\hline Alveolar-arterial oxygen gradient & $<50.9$ & $\begin{array}{l}\text { Impaired diffusion or shunting } \\
\text { (http://www-users.med.cornell.edu/ spon/picu/calc/aagrad.htm) }\end{array}$ \\
\hline Oxygenation index & 3.7 & $\begin{array}{l}\text { Denotes risk of treatment } \\
\text { (http://www-users.med.cornell.edu/ spon/picu/calc/oxyindex.htm) }\end{array}$ \\
\hline $\mathrm{PaO}_{2} / \mathrm{FiO}_{2}$ ratio & $>271$ & $\begin{array}{l}\text { Severity of lung injury: ALI }<300, \text { ARDS }<200 \\
\text { (http://easycalculation.com/medical/ALI.php) }\end{array}$ \\
\hline$Q_{s} / Q_{t}$ & $<4 \%$ & $\begin{array}{l}\text { Intrapulmonary shunt and V/Q mismatch, normally }<5 \% \\
\text { (http://www.medfixation.com/classic-shunt-equation-qsqt-calculation/) }\end{array}$ \\
\hline
\end{tabular}

$\mathrm{Q}_{s} / \mathrm{Q}_{t}=\left(\mathrm{CcO}_{2}-\mathrm{CaO}_{2}\right) /\left(\mathrm{CcO}_{2}-\mathrm{CvO}_{2}\right)$. The oxygen content of mixed arterial blood $\left(\mathrm{CaO}_{2}\right)$ is determined by the content of oxygen in the blood that reached ventilated alveoli $\left(\mathrm{CcO}_{2}\right)$, the content of oxygen in blood that bypassed ventilated alveoli $\left(\mathrm{CvO}_{2}\right)$, and the proportion of the two. $\mathrm{CcO}_{2}$ is the content of oxygen in pulmonary capillary blood and is estimated by plugging in $100 \%$ as the saturation since the $\mathrm{PcO}_{2}$ (pulmonary capillary $\mathrm{PO}_{2}$ ) can be assumed to be high enough to assure $100 \%$ saturation.

Mean airway pressure in a spontaneous breathing neonate is assumed to be $10 \mathrm{cmH}_{2} \mathrm{O}$.

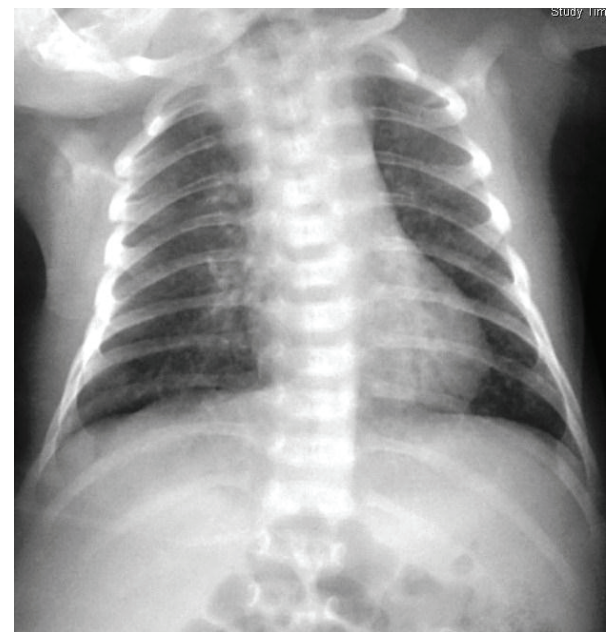

FIGURE 1: Diffuse patchiness on chest radiography in a neonate with Chlamydia trachomatis.

be $10 \mathrm{cmH}_{2} \mathrm{O}$. These respiratory equations indicate that the patient is only mildly affected despite abnormal chest radiography. Intrapulmonary shunting $\left(Q_{s} / Q_{t}\right)$ assesses ventilationperfusion mismatch $[7,8]$. In room air and with assumption that mixed venous oxygen saturation was $75 \%$, intrapulmonary shunting was estimated to be normal in this neonate.

The literature review further suggests that it is necessary to treat neonatal chlamydial pneumonitis despite the mild clinical manifestations [9-13]. For the treatment of chlamydial ophthalmia or pneumonia, oral erythromycin for 2 weeks is recommended; additional topical therapy is unnecessary. However, in approximately $20 \%-30 \%$ of infants, therapy will not eradicate the organism and the infant may require a repeat oral course of antibiotics [13]. Neonatal chlamydial pneumonitis is a creepy diagnosis. Classically, chest radiography appearance may be much worse than the neonate's clinical appearance. In an otherwise afebrile well infant, treatment with a full course of macrolide antibiotic is still indicated.

\section{References}

[1] W. Guo, Y. Li, A. Jiao, Y. Peng, D. Hou, and Y. Chen, “Tracheoesophageal fistula after primary repair of type $\mathrm{C}$ esophageal atresia in the neonatal period: recurrent or missed second congenital fistula," Journal of Pediatric Surgery, vol. 45, no. 12, pp. 2351-2355, 2010.

[2] J. D. Cherry, T. Tan, C. H. Wirsing von Konig et al., "Clinical definitions of pertussis: summary of a Global Pertussis Initiative roundtable meeting, February 2011," Clinical Infectious Diseases, vol. 54, no. 12, pp. 1756-1764, 2012.

[3] S. Guillot, G. Descours, Y. Gillet, J. Etienne, D. Floret, and N. Guiso, "Macrolide-resistant Bordetella pertussis infection in newborn girl, France," Emerging Infectious Diseases, vol. 18, no. 6, pp. 966-968, 2012.

[4] I. G. Rours, M. R. Hammerschlag, A. Ott et al., "Chlamydia trachomatis as a cause of neonatal conjunctivitis in Dutch infants," Pediatrics, vol. 121, no. 2, pp. e321-e326, 2008.

[5] A. Artigas, G. R. Bernard, J. Carlet et al., "The AmericanEuropean Consensus Conference on ARDS-part 2: ventilatory, pharmacologic, supportive therapy, study design strategies, and issues related to recovery and remodeling. Acute respiratory distress syndrome," American Journal of Respiratory and Critical Care Medicine, vol. 157, no. 4, part 1, pp. 1332-1347, 1998.

[6] A. Artigas, "Current definitions of acute lung injury and the acute respiratory distress syndrome," Intensive Care Medicine, vol. 26, no. 7, p. 1019, 2000.

[7] D. Hess and C. Maxwell, "Which is the best index of oxygenation: $\mathrm{P}(\mathrm{A}-\mathrm{a}) \mathrm{O}_{2}, \mathrm{PaO}_{2} / \mathrm{PAO}_{2}$, or $\mathrm{PaO}_{2} / \mathrm{FIO}_{2}$ ?" Respiratory Care, vol. 30, no. 11, pp. 961-963, 1985.

[8] W. M. Granger, "Evaluating the oxygen-tension-based indices of venous admixture: an overview," Respiratory Care, vol. 41, no. 7, pp. 607-610, 1996. 
[9] I. Stock and B. Henrichfreise, "Infections with Chlamydia trachomatis," Medizinische Monatsschrift für Pharmazeuten, vol. 35, no. 6, pp. 209-222, 2012.

[10] J. Sarlangue and C. Castella, "Chlamydia infection in neonates and infants," Archives de Pediatrie, vol. 12, supplement 1, pp. S32S34, 2005.

[11] M. Pokrzywnicka, P. Krajewski, and M. Kwiatkowska, "Chlamydia infections in the neonatal period," Medycyna Wieku Rozwojowego, vol. 9, no. 1, pp. 65-69, 2005.

[12] C. Bekler, N. Kultursay, T. Ozacar, A. Sayiner, M. Yalaz, and M. Akisu, "Chlamydial infections in term and preterm neonates," Japanese Journal of Infectious Diseases, vol. 65, no. 1, pp. 1-6, 2012.

[13] H. J. Zar, "Neonatal chlamydial infections: prevention and treatment," Pediatric Drugs, vol. 7, no. 2, pp. 103-110, 2005. 


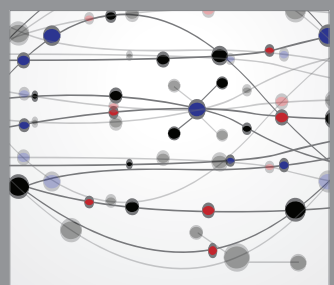

The Scientific World Journal
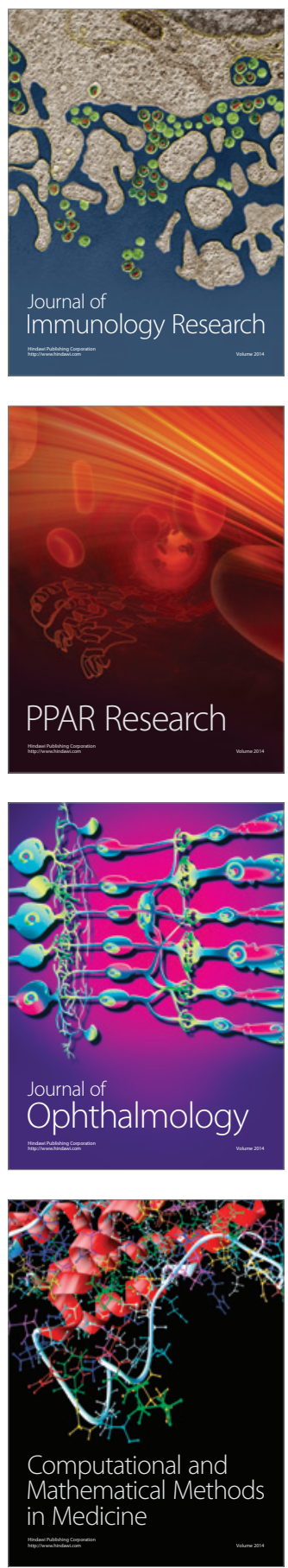

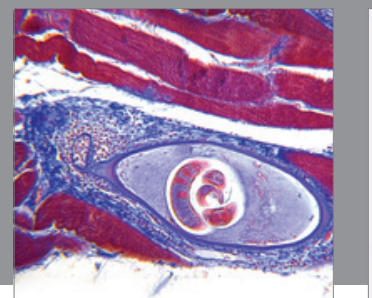

Gastroenterology

Research and Practice
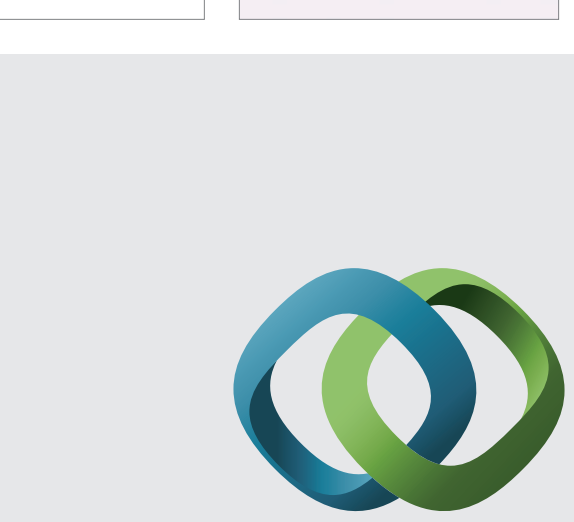

\section{Hindawi}

Submit your manuscripts at

http://www.hindawi.com
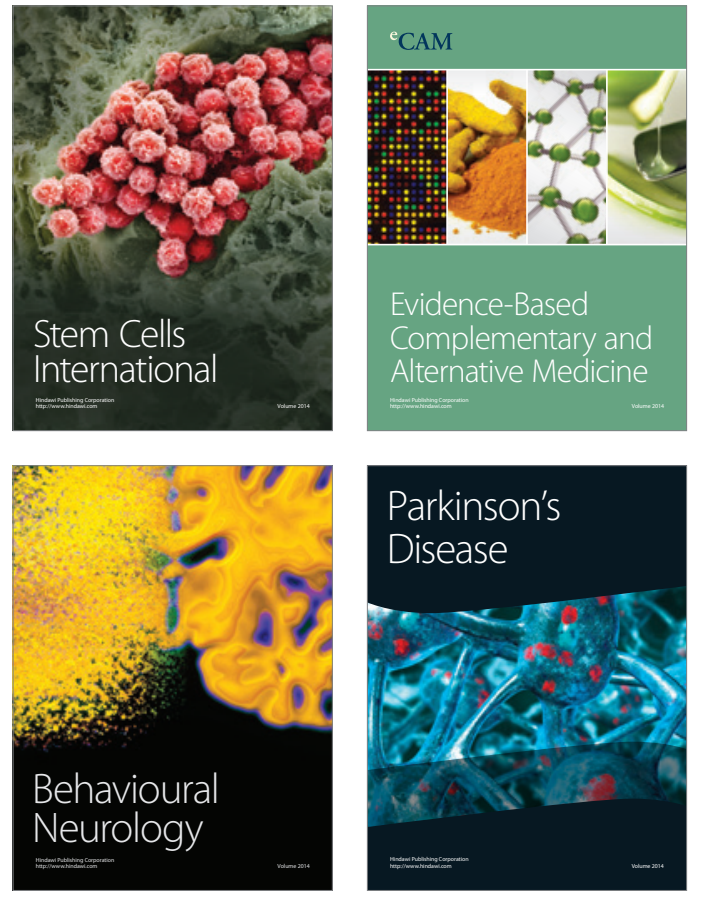
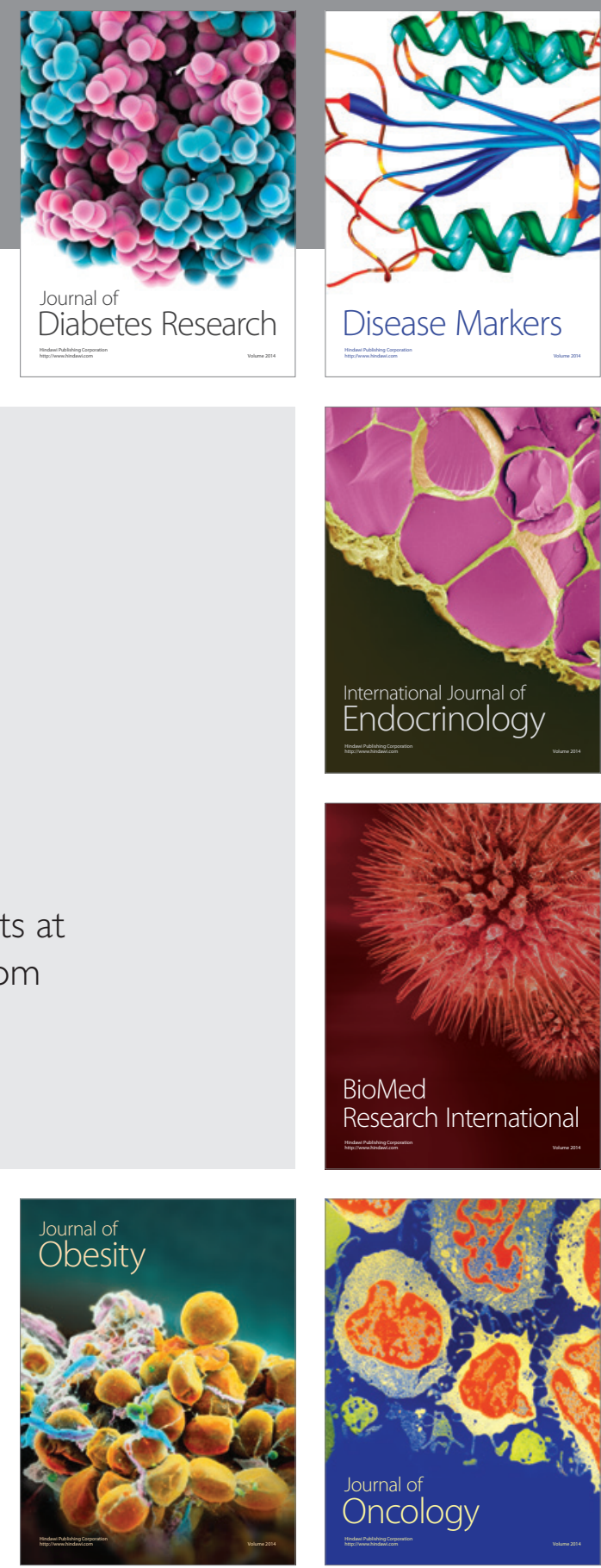

Disease Markers
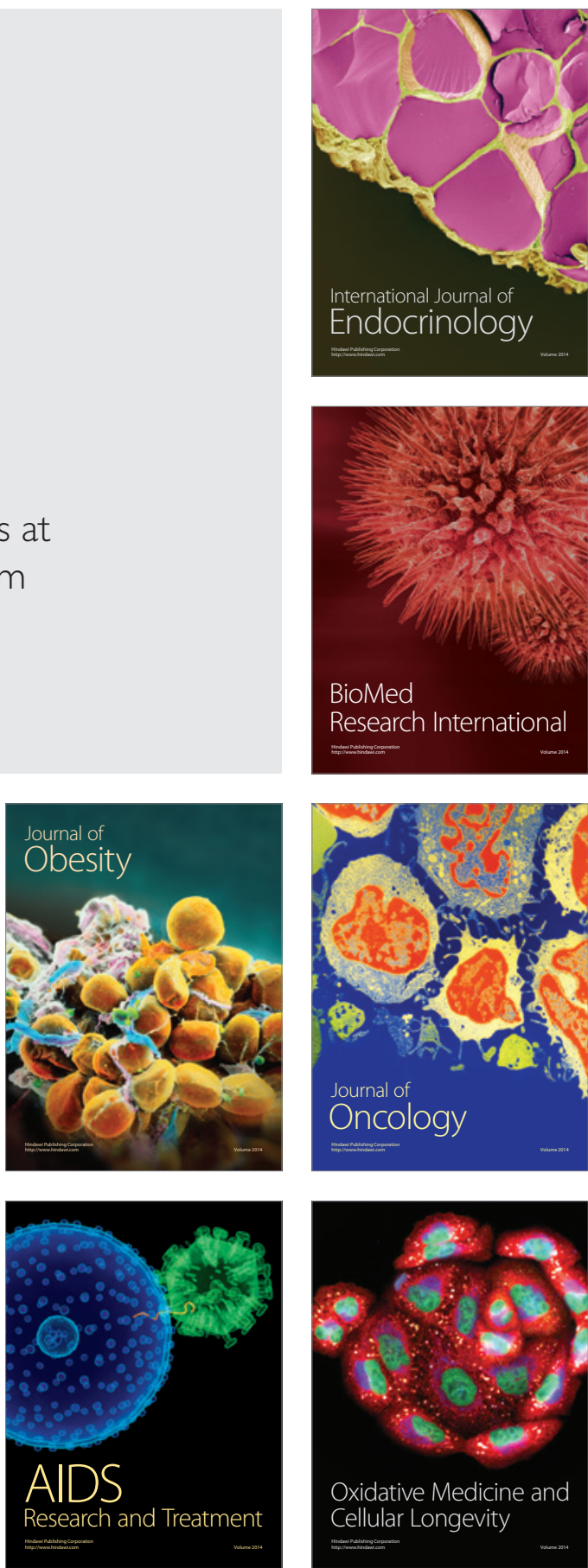